\title{
Quantitative landscape reconstruction and erosion history during the past 1,100 years in the Skogaryd Research Catchment, southern Sweden
}

\author{
Bingjie Yang $^{1}$ (D) Anne Birgitte Nielsen ${ }^{1} \cdot$ Karl Ljung $^{1} \cdot$ Elise Fahlgren $^{2} \cdot$ Anne Hormes $^{2} \cdot$ Dan Hammarlund $^{1}$
}

Received: 27 May 2019 / Accepted: 18 January 2020 / Published online: 29 January 2020

(c) The Author(s) 2020

\begin{abstract}
A sediment sequence from a small forest lake in southwestern Sweden was investigated to explore the effects of forestry and land-use on catchment erosion and delivery of organic and minerogenic matter to the lake. Catchment-scale vegetation changes during the last 1,100 years were reconstructed quantitatively at 50-year resolution using pollen analysis and the Landscape reconstruction algorithm (LRA). Variations in terrestrial organic matter input to lake sediments were assessed by total organic carbon (TOC) content and carbon to nitrogen $(\mathrm{C} / \mathrm{N})$ ratios. Changes in minerogenic matter were analysed using X-ray fluorescence (XRF) scanning. The results show that Skogaryd was not intensively used for agriculture throughout the past 1,100 years, but its land-use changes were very sensitive to societal changes. Between ca. AD 950 and 1350, local land-use was characterized by small-scale agricultural activities associated with the Medieval expansion, and enhanced soil erosion was recorded by increased K, Ti and Rb deposition. Around AD 1350 much of the farmland was abandoned, most likely in response to outbreaks of plague. The abandonment of farmland caused increased coniferous woodland cover and lower soil erosion. From the 16th century land-use expanded and gradually intensified, concurrent with a population increase documented in the study area between ca. AD 1600 and 1850. Intensive exploitation of the forest led to soil erosion and increased terrestrial organic and minerogenic matter export to the lake. These processes peaked with the artificial drainage of a nearby wetland for agricultural purposes. During the 20th century, modern forestry management started with the plantation of conifers, and soil erosion declined.
\end{abstract}

Keywords Land-use $\cdot$ Organic matter $\cdot$ Pollen $\cdot$ Landscape reconstruction algorithm $\cdot$ Soil erosion

\section{Introduction}

Human activities including agriculture, forest clearance and industrialization have been the main cause of vegetation changes during the past 1,000 years in Europe. The

Communicated by M.-J. Gaillard.

Electronic supplementary material The online version of this article (https://doi.org/10.1007/s00334-020-00770-6) contains supplementary material, which is available to authorized users.

Bingjie Yang

bingjie.yang@geol.lu.se

1 Quaternary Sciences, Department of Geology, Lund University, Sölvegatan 12, 22362 Lund, Sweden

2 Department of Earth Sciences, University of Gothenburg, Guldhedsgatan 5a, 41320 Gothenburg, Sweden population experienced several phases of growth and decline during this period. Population growth led to the expansion of agricultural land and increased erosion, which resulted in generally increased detrital input to lakes (Williams 2000; Boyle 2001; Koinig et al. 2003; Bragée et al. 2013). The increased detrital input associated with more intensive land use caused eutrophication and increased aquatic primary productivity in lake waters (Neumann et al. 2002; Routh et al. 2004; Köster et al. 2005; Li et al. 2008). During periods of population decrease, lake ecosystems may return to natural conditions, but such recovery can take decades or even centuries (Haas et al. 2019), and if critical thresholds have been crossed, the ecosystem may never return to the preimpact state (Duarte et al. 2009; Randsalu-Wendrup et al. 2016). Long-term records of vegetation and aquatic environmental changes at centennial to millennial time scales are therefore essential for the assessment of ecosystem dynamics in response to early and recent anthropogenic disturbances, 
and such data have significance for nature conservation (Willis and Birks 2006; Mazier et al. 2015). Since lake sediments are influenced by terrestrial input, it is possible to reconstruct environmental changes in lake catchments based on multi-proxy analysis of continuous lake sediment records (Koinig et al. 2003; Meyers 2003; Klamt et al. 2017).

The long-term history of human impact on vegetation can be reconstructed by means of pollen analysis. However, it is difficult to quantify vegetation dynamics based on pollen percentages without taking the difference in pollen productivity and dispersal into consideration. Thus, the Landscape reconstruction algorithm (LRA) has been developed to quantify vegetation cover based on pollen assemblages, pollen productivity and dispersal (Sugita 2007a, b). The LRA is dependent on two models, REVEALS (Regional Estimates of VEgetation Abundance from Large Sites), which is used to estimate regional vegetation composition (Sugita 2007a), and LOVE (LOcal Vegetation Estimates), which is used to estimate local vegetation composition in the same region (Sugita 2007b). Over the last decade, frequent applications in Europe have shown that LRA gives a better estimate of past land cover and can discriminate between local and regional changes (e.g. Nielsen and Odgaard 2010; Overballe-Petersen et al. 2013; Cui et al. 2013, 2014; Hultberg et al. 2015; Mazier et al. 2015; Mehl et al. 2015; Abraham et al. 2017; Fredh et al. 2017, 2019; Hjelle and Lødøen 2017). Hence, the application of LRA makes it possible to quantify past local land-use changes.

The Skogaryd Research Catchment (SRC) station was established with the aim of improving the understanding of the roles of greenhouse gas balances and other biogeochemical cycles for regulating ecosystem services in the forested regions of the hemiboreal zone (https://gvc.gu.se/english/ research/skogaryd). A range of field experiments and monitoring series are in operation to characterize and quantify greenhouse gas balances, including carbon and nitrogen exchange between land and atmosphere (e.g. Klemedtsson et al 2010; Rütting et al. 2014; Tarvainen et al. 2014), land and water (e.g. Chmiel et al. 2016; Campeau et al. 2018) and water and atmosphere (e.g. Kokic et al. 2016; Wallin et al. 2018). However, there is no long-term monitoring data available beyond the last few decades. Documentation of prehistoric remnants, property maps, ownership changes and forestry accounts around the SRC indicate that large changes in land-use have taken place during the recent centuries (Hill 1999), affecting geochemical cycling in the area. It will be beneficial for contemporary studies to understand the history of agriculture and forestry in the SRC, and its consequences for biogeochemical processes, particularly the carbon cycles in a long-term perspective. In this study, we explore how land-use changes (e.g. forestry, agriculture, drainage patterns) have affected soil erosion in the catchment and nutrient input to the lake, through pollen analysis and catchment-related geochemical proxies obtained from the sediments from lake Skottenesjön in the SRC. The catchment-scale land-cover changes, in response to human impacts during the last 1,100 years, were reconstructed in quantitative terms through the application of LRA to pollen records. The soil erosion history and air-borne pollution were studied using the elemental intensity of $\mathrm{K}, \mathrm{Ti}, \mathrm{Rb}$ and $\mathrm{Zn}$ through $\mathrm{X}$-ray fluorescence, and the organic matter content in the sediment and the relative proportion of terrestrial organic matter input were assessed by the total organic carbon content (TOC) and carbon-to-nitrogen $(\mathrm{C} / \mathrm{N})$ ratio.

\section{Site description}

Lake Skottenesjön $\left(58^{\circ} 21^{\prime} \mathrm{N}, 12^{\circ} 08^{\prime} \mathrm{E}\right)$ (Fig. 1) is an elongated lake located downstream of SRC, in the county of Västra Götaland, southwestern Sweden. The lake is situated at an altitude of $60 \mathrm{~m}$ above sea level and has a surface area of 72 ha (Natchimuthu et al. 2016) with a maximum water depth of $6 \mathrm{~m}$ close to the inflow from Lake Gundlebosjön in the east, gradually shallowing towards the outflow in the west. Lake Skottenesjön has its main inflow from Lake Gundlebosjön and a few smaller streams and ditches, including the main ditch through the wetland Följemaden, draining the Skogaryd catchment.

Skogaryd is located in the hemi-boreal region (SITES 2015). The study area has a mean annual temperature of $6.2{ }^{\circ} \mathrm{C}$ and a mean annual precipitation of $709 \mathrm{~mm}$ according to the Vänersborg weather station, which is located $12 \mathrm{~km}$ east of Skogaryd. The catchment is mostly covered by mixed coniferous forest (Picea abies and Pinus sylvestris) with patches of farmland distributed along the shore of Lake Skottenesjön.

There are documentary records of human activities in the Skogaryd area since the mid-1600s, and several shifts in the land ownership, which could have an important influence on the land use, have been recorded since then (Hill 1999). The study area belonged to the local farmers at the farm Skottene prior to AD 1692, and was owned by the crown between AD 1692 and 1738 (Hill 1999). From $\mathrm{AD} 1738$, the right to use the forest in this area was leased to a steel factory, Kollerö Bruk, established in the early 1700s as the first steelworks in western Sweden (Hill 1999). From AD 1887, the right of land use by Kollerö Bruk was withdrawn (Hill 1999). In the 1870s, the central wetland Följemaden was partly drained by the establishment of the main ditch entering Lake Skottenesjön (Hill 1999). The drained mire was used for cultivation of oats while surrounding areas were used for pasture for a dairy farm (Hill 1999). The study area is part of Väne-Ryr Parish, and population data from AD 1571 to 1966 show that the population was steadily increasing 
Fig. 1 Location and modern land use of the study area and limits of the Skogaryd Research Catchment (SRC)
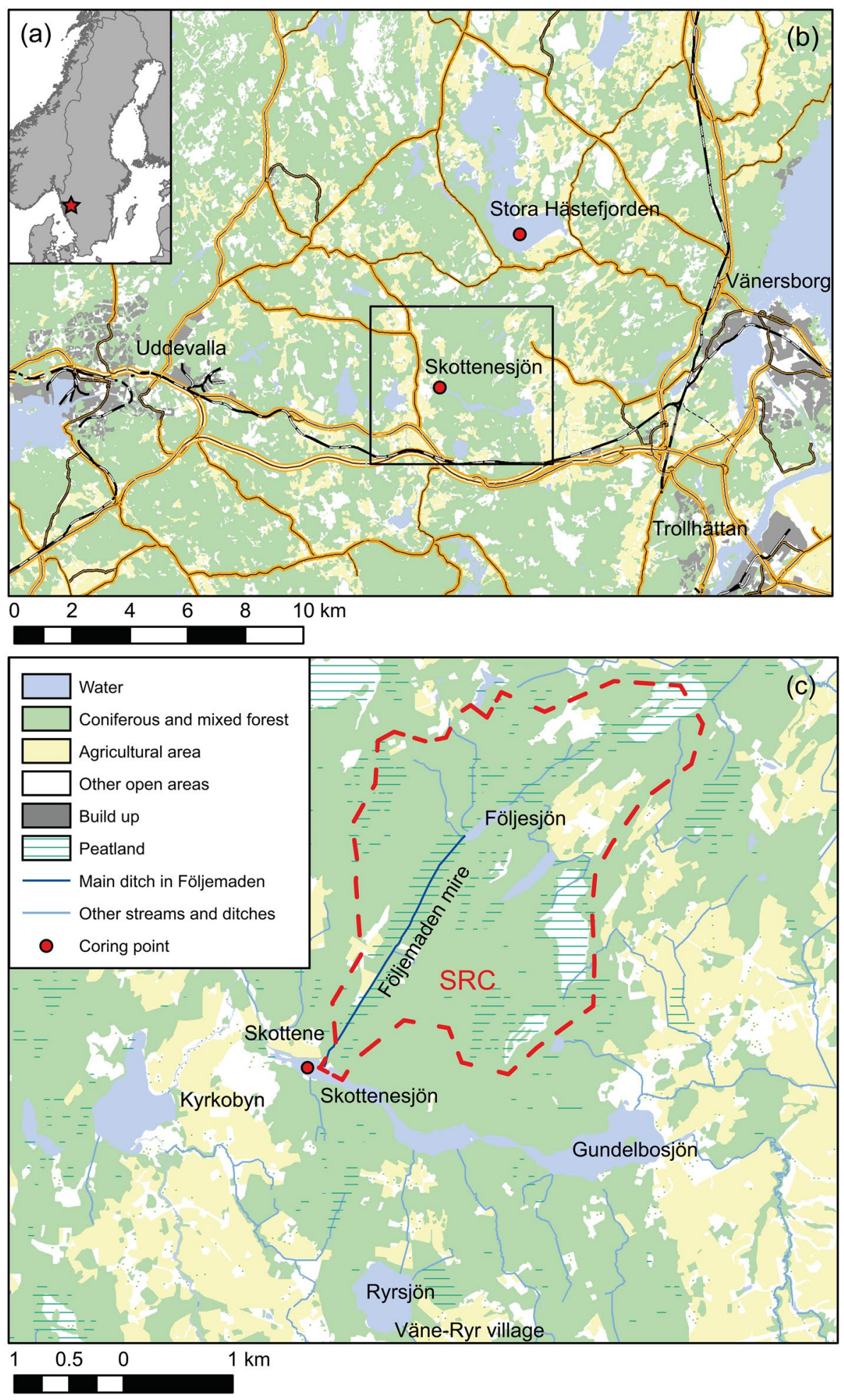

between $\mathrm{AD} 1571$ and 1880 and started to decline in the 20th century (Palm 2000). In terms of cultural landscape history before the historical records, the region is relatively little studied. Fries (1951) produced a transect of pollen diagrams from the wider region and two of them are located between Stora Hästefjorden and Vänersborg
(Fig. 1). These diagrams are not well dated, but in general, they indicate that the degree of human impact was low in the sites near our study region, compared to those at further west by the coast of Sweden. 


\section{Materials and methods}

\section{Sampling}

A $4.6 \mathrm{~m}$ long sediment sequence was retrieved from the western part of Lake Skottenejön close to the inlet of the main ditch at a water depth of $190 \mathrm{~cm}$ using a Russian corer (chamber length $1 \mathrm{~m} ; 75 \mathrm{~mm}$ in diameter) in January 2016. The core was collected with overlaps of approximately $60 \mathrm{~cm}$ between successive $1 \mathrm{~m}$ sections. The core segments were carefully correlated based on visible lithological changes and magnetic susceptibility (Thompson et al. 1980). The entire sediment sequence was subsampled contiguously at $1 \mathrm{~cm}$ intervals. The soft water-sediment interface and uppermost part $(17 \mathrm{~cm})$ were sampled with an HTH gravity corer with an inner diameter of $66 \mathrm{~mm}$ (Renberg and Hansson 2008) and subsampled at $1 \mathrm{~cm}$ intervals. The correlation between the uppermost Russian core segment and the gravity core sample sequence was based on $\mathrm{C} / \mathrm{N}$ ratios.

Another $1.8 \mathrm{~m}$ long sediment sequence was retrieved from the larger Lake Stora Hästefjorden (842 ha) located $5 \mathrm{~km}$ to the north of Lake Skottenesjön in May 2016. This sequence was used for pollen analysis and determination of regional land cover changes through the application of REVEALS in the LRA approach (Sugita 2007a).

\section{${ }^{210} \mathrm{~Pb}$ and ${ }^{14} \mathrm{C}$ dating}

Fifteen freeze-dried samples from the uppermost part of the Lake Skottenesjön sediment sequence and 14 from the Stora
Hästefjorden sequence were submitted to the Environmental Radiometric Facility, University College London for the analysis of ${ }^{210} \mathrm{~Pb},{ }^{226} \mathrm{Ra},{ }^{137} \mathrm{Cs}$ and ${ }^{241} \mathrm{Am}$ activity by direct gamma assay using an ORTEC HPGe GWL series welltype coaxial low background intrinsic germanium detector. Dates were determined using the constant rate of ${ }^{210} \mathrm{~Pb}$ supply (CRS) model (Appleby 2001).

Accelerator-mass-spectrometry (AMS) ${ }^{14} \mathrm{C}$ dating of terrestrial plants remains was applied for dating of the lower sections of the sediment sequences beyond the reach of ${ }^{210} \mathrm{~Pb}$ dating. Sediment sections from selected levels in the Russian cores were wet sieved, after which terrestrial macroscopic plant remains were carefully picked out under the microscope at $\times 15$ magnification. Eight samples from Skottenesjön and four from Stora Hästefjorden were dated at the Radiocarbon Dating Laboratory, Department of Geology, Lund University (Table 1). All ${ }^{14} \mathrm{C}$ dates were calibrated using the IntCal13 radiocarbon calibration dataset (Reimer et al. 2013). The age-depth models of the whole sediment sequences were established based on the combination of ${ }^{210} \mathrm{~Pb}$ and ${ }^{14} \mathrm{C}$ dates in the R-code CLAM (Blaauw 2010).

\section{Pollen analysis and landscape reconstruction}

A total of 29 sediment samples $\left(1 \mathrm{~cm}^{3}\right.$ in volume $)$ from Skottenesjön and 21 from Stora Hästefjorden were collected for pollen counting from the gravity cores and the uppermost Russian core segments which cover the last 1,100 years. The samples were prepared following the standard acetolysis method (Berglund and Ralska-Jasiewiczowa 1986). In each sample, at least 1,000 pollen grains were counted under an

Table 1 Accelerator-mass-spectrometry (AMS) ${ }^{14} \mathrm{C}$ dates from Lake Skottenejön and Lake Stora Hästefjorden

\begin{tabular}{|c|c|c|c|c|c|}
\hline Depth $(\mathrm{cm})$ & Dated material & Weight (mg C) & Lab no & Radiocarbon age (вр) & $\begin{array}{l}\text { Calibrated age } \\
\text { (cal BP, } 2 \sigma \text { range) }\end{array}$ \\
\hline \multicolumn{6}{|l|}{ Skottenesjön } \\
\hline $43-45$ & Twig, Betula fruits and catkin & 0.6 & LuS 12229 & $1,620 \pm 40$ & $1,410-1,573$ \\
\hline $93-95$ & Leaf and twig & 0.8 & LuS 12230 & $2,950 \pm 40$ & $2,975-3,214$ \\
\hline $133-135$ & Twig & 1.8 & LuS 12231 & $3,895 \pm 35$ & $4,235-4,422$ \\
\hline $187-189$ & Twig and Betula fruits & 1.4 & LuS 12232 & $5,010 \pm 50$ & $5,647-5,898$ \\
\hline $241-243$ & Bark, twig, catkin & 0.5 & LuS 12233 & $6120 \pm 45$ & $6,896-7,158$ \\
\hline $287-289$ & Leaf & 0.7 & LuS 12234 & $7,185 \pm 45$ & $7,936-8,062$ \\
\hline $341-343$ & Twig, leaf & 0.7 & LuS 12235 & $8,200 \pm 50$ & $9,017-9,296$ \\
\hline $387-389$ & Twig & 1.6 & LuS 12236 & $8,365 \pm 45$ & $9,283-9,482$ \\
\hline \multicolumn{6}{|c|}{ Stora Hästefjorden } \\
\hline $44-46$ & Small macrofossils & 0.4 & LuS 13509 & $1,585 \pm 40$ & $1,392-1,554$ \\
\hline $74-76$ & Small macrofossils & 0.5 & LuS 13510 & $2,390 \pm 45$ & $2,337-2,516$ \\
\hline $102-104$ & Small macrofossils & 0.6 & LuS 13511 & $4,305 \pm 45$ & $4,823-4,976$ \\
\hline $133-136$ & Small macrofossils & 0.4 & LuS 13512 & $7,130 \pm 50$ & $7,912-8,025$ \\
\hline
\end{tabular}

$L u S$ lund university radiocarbon dating laboratory

${ }^{a 14} \mathrm{C}$ dates were calibrated using the IntCal13 radiocarbon calibration dataset (Reimer et al. 2013) 
Olympus BX41 microscope at $\times 400$ magnification at the Department of Geology, Lund University.

Pollen counts at an interval of approximately 50 years were later converted to the estimated percentages of vegetation composition to reconstruct land-use changes through the application of REVEALS and LOVE in the LRA model. REVEALS estimates require pollen records from a large lake ( $>100 \mathrm{ha}$ ) to reconstruct regional vegetation cover (Sugita 2007a). This was then used in the LOVE model (Sugita 2007b) to distinguish the regional pollen deposition from the local at the smaller target site. Therefore, pollen counts from Lake Stora Hästefjorden were used in the REVEALS model for estimating the regional vegetation composition. Thereafter, the regional vegetation estimates together with the pollen counts from Lake Skottenesjön were used in the LOVE model to estimate the vegetation composition within the local pollen catchment. The pollen dispersal model underlying the LRA assumes that wind above the canopy is the dominant vector for pollen transport. Lake Skottenesjön, which has an inflow from the east and a few small streams (Fig. 1), is not a closed basin so it is to be expected that some pollen also arrives at the lake by water (Tauber 1977). However, the coring site is located in the western basin of the lake, far away from the inflow, and most of the small streams are connected to the eastern basin of the lake. Furthermore, the lake is shallowing towards the west, so it's very likely that most waterborne pollen is sedimented in the eastern part of the lake and does not reach the coring site. Therefore the use of the LOVE model was based on the assumption that the pollen at the coring site is predominantly derived from atmospheric sources. The programs REVEALS.v5.0 and LOVE.v5.1 were used for REVEALS and LOVE analysis respectively (Sugita unpublished). The LRA modelling was carried out based on 25 selected taxa which represent more than $90 \%$ of the pollen in the pollen records and have reliable estimates of relative pollen productivity (RPP) for the study region. The RPP estimates and fall speeds of pollen applied in the LRA analysis are shown in Table 2. The lake area was assumed constant, atmospheric conditions were assumed to be neutral and the wind speed was set to $3 \mathrm{~m} / \mathrm{s}$ throughout the studied time period.

\section{Geochemical analyses}

$\mathrm{K}$, Ti and $\mathrm{Rb}$ within the XRF data set are chosen to assess changes in minerogenic input to the lake due to erosion, as they are associated with clay minerals and are frequently used as indicators of detrital input in the lake sediments (e.g. Das and Haake 2003; Koinig et al. 2003; Balascio et al. 2011; Kylander et al. 2011; Aufgebauer et al. 2012; $\mathrm{Lu}$ et al. 2017). $\mathrm{Zn}$ is also included as it is an important airborne pollutant that could be derived from mining, burning coal and gasoline, the dust from automobile tyres
Table 2 Pollen productivity estimates (PPE) relative to Poaceae and fall speeds of the taxa used in the LRA

\begin{tabular}{|c|c|c|}
\hline Pollen taxa & PPE & Fall speed $(\mathrm{m} / \mathrm{s})$ \\
\hline Pinus & $5.663^{\mathrm{a}}$ & $0.031^{\mathrm{b}}$ \\
\hline Picea & $1.757^{\mathrm{a}}$ & $0.056^{\mathrm{b}}$ \\
\hline Quercus & $7.533^{\mathrm{a}}$ & $0.035^{\mathrm{b}}$ \\
\hline Fagus & $6.667^{\mathrm{a}}$ & $0.057^{\mathrm{c}}$ \\
\hline Ulmus & $1.267^{\mathrm{a}}$ & $0.032^{\mathrm{c}}$ \\
\hline Tilia & $0.8^{\mathrm{a}}$ & $0.032^{\mathrm{c}}$ \\
\hline Fraxinus & $0.667^{\mathrm{a}}$ & $0.022^{\mathrm{b}}$ \\
\hline Alnus & $4.2^{\mathrm{a}}$ & $0.021^{\mathrm{b}}$ \\
\hline Betula & $8.867^{\mathrm{a}}$ & $0.024^{\mathrm{b}}$ \\
\hline Corylus & $1.4^{\mathrm{a}}$ & $0.025^{\mathrm{c}}$ \\
\hline Salix & $1.267^{\mathrm{a}}$ & $0.022^{\mathrm{c}}$ \\
\hline Juniperus & $2.067^{\mathrm{a}}$ & $0.016^{\mathrm{b}}$ \\
\hline Calluna & $1.102^{\mathrm{d}}$ & $0.038^{\mathrm{e}}$ \\
\hline Poaceae & 1 & $0.035^{\mathrm{a}}$ \\
\hline Filipendula & $2.48^{\mathrm{e}}$ & $0.006^{\mathrm{e}}$ \\
\hline Rumex acetosella & $1.559^{\mathrm{d}}$ & $0.018^{\mathrm{e}}$ \\
\hline Plantago lanceolata & $0.897^{\mathrm{d}}$ & $0.029^{\mathrm{e}}$ \\
\hline Plantago media/major & $1.27^{\mathrm{f}}$ & $0.024^{\mathrm{f}}$ \\
\hline Artemisia & $3.48^{g}$ & $0.025^{\mathrm{h}}$ \\
\hline Chenopodiaceae & $4.28^{\mathrm{i}}$ & $0.019^{\mathrm{i}}$ \\
\hline Asteraceae Cichorioideae & $0.244^{\mathrm{e}}$ & $0.051^{\mathrm{e}}$ \\
\hline Apiaceae & $0.26^{\mathrm{j}}$ & $0.042^{\mathrm{c}}$ \\
\hline Cyperaceae & $1.002^{\mathrm{a}}$ & $0.035^{\mathrm{a}}$ \\
\hline Secale cereale & $3.017^{\mathrm{a}}$ & $0.06^{\mathrm{c}}$ \\
\hline Cerealia-t & $0.747^{\mathrm{d}}$ & $0.06^{\mathrm{e}}$ \\
\hline
\end{tabular}

${ }^{\text {a}}$ Sugita et al. 1999

${ }^{\mathrm{b}}$ Eisenhut 1961

${ }^{\mathrm{c}}$ Gregory 1973

${ }^{\mathrm{d}}$ Nielsen 2004

${ }^{\mathrm{e}}$ Broström et al. 2004

${ }^{\mathrm{f}}$ Mazier et al. 2008

${ }^{\mathrm{h}}$ Mazier et al. 2012

i Abraham and Kozáková 2012

${ }^{\mathrm{j}}$ Hjelle 1998

and industrial waste (Shotyk 1996; Espi et al. 1997; Olid et al. 2010). The surface-cleaned sediment core sections from Skottenesjön were analysed for X-ray fluorescence (XRF) using an Itrax Core Scanner at the Natural History Museum of Denmark, Copenhagen. The XRF scanner was operated at $50 \mathrm{kV}$ and $30 \mathrm{~mA}$ with a count time of $35 \mathrm{~s}$ and a step size of $1,000 \mu \mathrm{m}$. The average intensity of each element was calculated at every centimetre (e.g. the average of 10 measurements) based on micro-XRF elemental profiles. The elemental data produced by ITRAX are qualitative, and the results are presented as counts per second (cps) (Croudace et al. 2006; Davies et al. 2015). 
TOC content of lake sediments reflects the amount of organic matter in the lake sediments. Aquatic organic matter generally exhibits lower $\mathrm{C} / \mathrm{N}$ ratios than terrestrial organic matter, so increases in $\mathrm{C} / \mathrm{N}$ ratio indicate higher input of terrestrial organic matter to lake sediments (Meyers 1994; Guilizzoni et al. 1996). Thus, TOC content and C/N ratio are used to reflect variations in amount and composition of organic matter in the lake sediment attributed to enhanced soil erosion associated with human activities. Each subsample of the top $52 \mathrm{~cm}$ of the sediment sequence was analysed for bulk organic carbon content (TOC) and total nitrogen content (TN). We assumed that there was no carbonate (inorganic carbon) present in the lake sediment since the lake and its catchment are situated on crystalline bedrock with acidic soils. Subsamples were freeze-dried, homogenized and weighed, followed by analysis using an elemental analyser (Sercon SL, Sercon Ltd) at the Department of Earth Sciences, Gothenburg University. Based on a cross plot of TOC and TN data (Talbot 2001), inorganic nitrogen was insignificant except in the topmost four samples. The $\mathrm{C} / \mathrm{N}$ ratios were calculated using the weight percentages of $\mathrm{C}$ and $\mathrm{N}$, which were then converted to atomic ratios by multiplying by 1.167 (Meyers and Teranes 2001).

\section{Results}

\section{Chronology}

The age-depth models of the sediment sequences from Skottenejön and Stora Hästefjorden were established based on the ${ }^{210} \mathrm{~Pb}$ and ${ }^{14} \mathrm{C}$ dating (Fig. 2). The sediment sequence of Skottenejön spans from ca. 9,400 cal вр to the present. A rapid accumulation with an average sedimentation rate of $0.17 \mathrm{~cm} /$ year is indicated from the beginning of lake sediment accumulation after isolation from the sea at 9,000-10,000 BP (Björck and Digerfeldt 1991; Sveriges
Geologiska Undersökning (SGU) 2016). The sediment accumulation rate was rather constant (around $0.04 \mathrm{~cm} /$ year) from ca. 8,900 to 2,300 cal BP. From ca. 2,300 to ca. $200 \mathrm{cal} \mathrm{BP}$, the sediment accumulation rate decreased to ca. $0.02 \mathrm{~cm} /$ year, followed by a rapid increase to $0.25 \mathrm{~cm} /$ year over the last ca. 250 years. The sediment sequence of Stora Hästefjorden spans from ca. 8,000 cal BP to the present, and has a rather constant accumulation rate of around $0.01 \mathrm{~cm} /$ year from ca. 8,000 to 2,500 cal BP. From ca. 2,500 to $1,500 \mathrm{cal} \mathrm{BP}$, the sediment accumulation rate increased to $0.03 \mathrm{~cm} /$ year, followed by a drop to $0.02 \mathrm{~cm} /$ year after ca. $1,500 \mathrm{cal} \mathrm{BP}$, and then increased very rapidly over the last ca. 150 years. The very high accumulation rates in the top part of both sediment sequences are primarily attributed to less compacted sediments. In the following, the ages are referred to as calendar years $\mathrm{AD}$, as the study focuses on the most recent millennium.

\section{Land cover reconstruction}

Figure 3 presents the estimated vegetation cover percentages of the 25 pollen taxa included in the LOVE model. Four zones were established by visual inspection of the vegetation estimates diagram with reference to a constrained cluster analysis based on CONISS. The original pollen diagram can be seen in the Supplementary Material (ESM 1 Fig. 1). The estimated vegetation cover shows a much higher degree of landscape openness than the original Non-Arboreal Pollen (NAP) percentages. Additionally, pronounced changes in the forest composition are observed when comparing with original pollen percentages. The diagram of estimated vegetation cover (Fig. 3) demonstrates that Picea was the major species during most of the study period. Open land associated with human activities including deforestation, cultivation and animal grazing covered approximately an average of $44 \%$ of the studied landscape, with variations in the different land-use periods. The relevant source area of pollen (RSAP) estimates
Fig. 2 Age-depth models based on the combination of ${ }^{210} \mathrm{~Pb}$ and ${ }^{14} \mathrm{C}$ dates in the R-code CLAM (Blaauw 2010); a agedepth model for the sediment sequence from Lake Skottenesjön. b Age-depth model for the sediment sequence from Lake Stora Hästefjorden. Details of the radiocarbon dates are given in Table 1
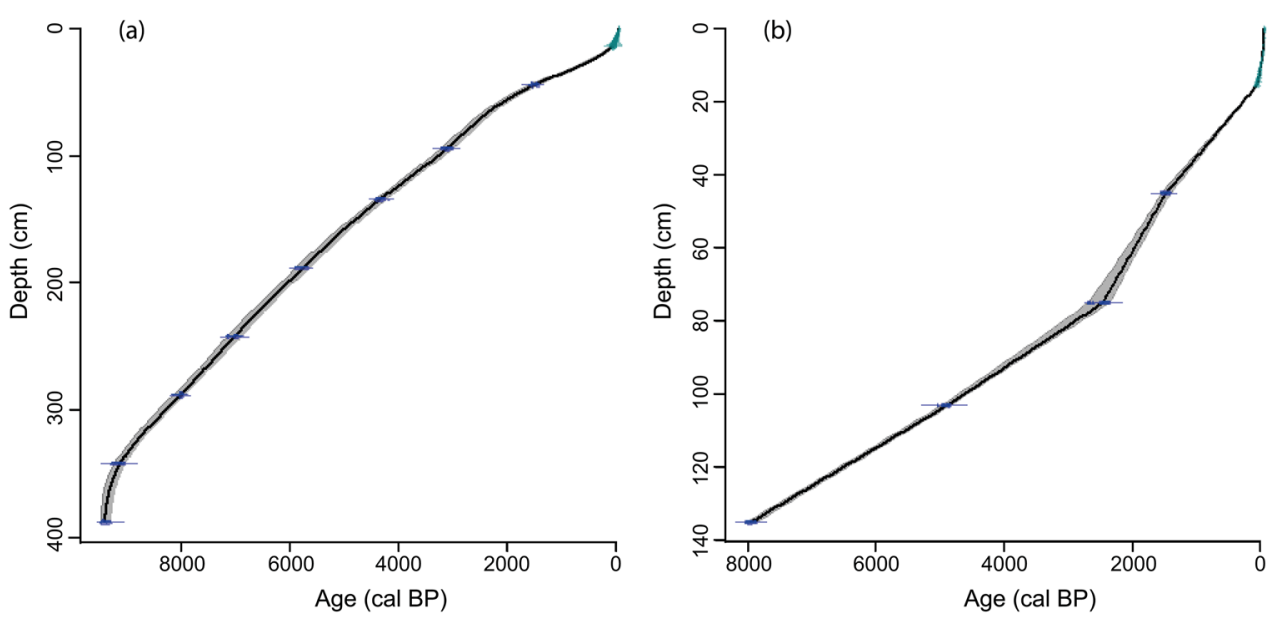


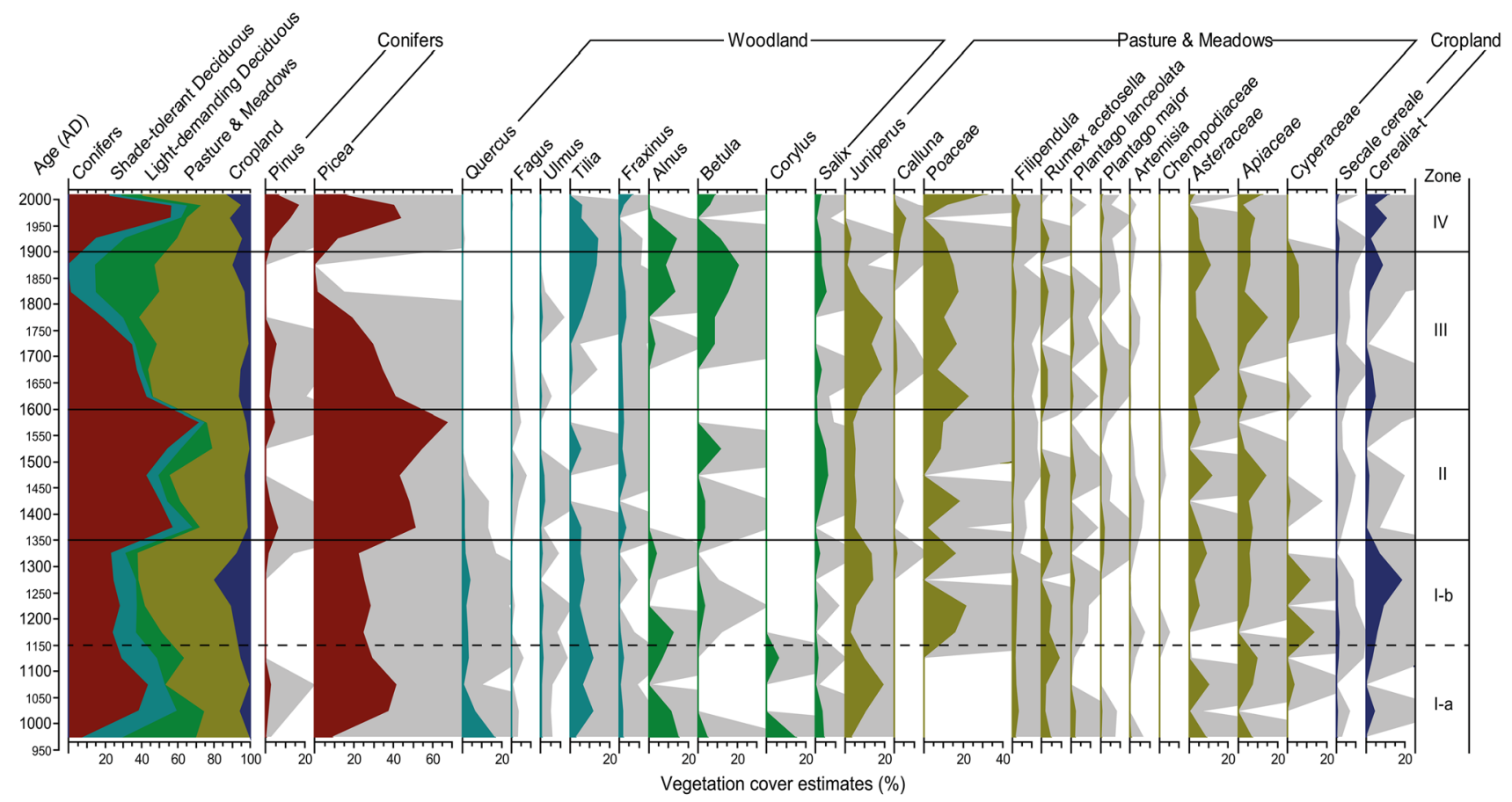

Fig. 3 LOVE-based estimates of local vegetation composition in percentages within the relevant source area of pollen for 25 selected taxa from Lake Skottenesjön. The pollen counts from Lake Stora Hästefjorden have been used to estimate the regional background pollen input based on the LRA-REVEALS model (ESM 1 Figs. 2 and

from LRA-LOVE range from 250 to 2,000 m, with the highest values occurring in the late Medieval period and the 19th century (ESM 2). However, the RSAP has to be interpretated cautiously since only one lake is used in the LOVE analysis. The standard errors of the vegetation cover estimates are also included in the Supplementary Material (ESM 2).

\section{Zone I (ca. AD 950-Ca. 1350)}

This zone can be divided into two sub-zones. In Zone I-a (ca. AD 950-ca. 1350), nearly $67 \%$ of the relevant pollen source area was covered by woodlands and a substantial increase is seen in conifers, particularly for Picea from 9 to $42 \%$. In contrast, deciduous trees cover decreased from 61 to $10 \%$, particularly for Quercus from 16 to $1 \%$. The open land dominated by pasture and meadows had an average cover of $34 \%$. Cropland covered less than 3\% of the area.

In Zone I-b (ca. AD 1150-ca. 1350), the open land increased to $57 \%$ on average, of which pasture and meadows (46\%) were the major land-use types. There was a high abundance of Cyperaceae (6\%). The cover of Poaceae (14\%) increased substantially within this zone. The cropland increased to $11 \%$, dominated by Cerealia-type. The cover of conifers declined to $26 \%$ dominated by Picea. The deciduous
3). Cerealia-t includes pollen of Hordeum-type and Triticum/Avenatype. The grey curves are $10 \times$ exaggerations of the percentage values. The zones represent land-use periods and are defined based on the variation of vegetation cover estimated by LOVE

woodland cover declined to $17 \%$, particularly for Quercus (3\%) and Alnus (4\%).

\section{Zone II (ca. AD 1350-Ca. 1600)}

This zone is characterized by high values in coniferous woodland cover, particularly for Picea, with an average value of $56 \%$. At the transition to zone II, Picea increased to $51 \%$ followed by a drop to $43 \%$ in the 1400 s and reached maximum values in the 1500 s with $68 \%$. Coniferous woodland cover increased at the expense of both deciduous woodland and open land cover. Shade-tolerant deciduous trees, particularly Quercus and Tilia, show a distinct decrease. The light-demanding trees dominated by Betula and Salix show an increase following the drop of Picea in the 1400s, and a decline continuing to Zone III-a. Reductions are seen in meadow and pastures (from 43 to 29\%), and even dramatically in cropland (from 10 to $1.7 \%$ ) compared to the previous zone.

\section{Zone III (ca. AD 1600-ca. 1900)}

A substantial decline is seen in the coniferous woodland cover, from $56 \%$ on average in the previous zone to $23 \%$ in this zone, particularly for Picea. The cover of Picea shows 
a drastic reduction throughout the zone, from $41 \%$ in the early 1600 s to its minimum in the late 1800 s. Meanwhile, the deciduous woodland cover increased from 14 to $23 \%$ on average, especially for the light-demanding pioneer trees. Betula and Alnus covered 19 and $12 \%$ of the lake catchment on average respectively in the 1800 s. Tilia also increased during this period. Open land increased to $54 \%$ at the expense of coniferous woodland. Pastures and meadows covered $50 \%$ of the area on average. Cropland dominated by Cerealia-type shows relatively high values $(5.5 \%)$ before ca. AD 1700 , followed by a decline during the 1700s and an increase again from the early 1800s.

\section{Zone IV (ca. AD 1900-ca. 2016)}

An expansion of coniferous woodland cover is observed in this zone. The cover of Pinus and Picea increased to 17\% and $44 \%$, respectively, before ca. AD 2000 , followed by declines in both Pinus and Picea in the early 21 st century.
The cover of deciduous trees declined, particularly for the light-demanding deciduous trees, which decreased from 29 to $8 \%$ within this zone. Open land covered approximately $40 \%$. The open land decreased before ca. AD 2000, followed by an increase to $60 \%$ in the 21 st century. A reduction is seen in Cyperaceae. There was a general increase in cropland (8\%), with a doubling of Cerealia-type compared to the previous zone, but a small decrease in the cover of Secale.

\section{XRF records}

The variations of the elemental intensity of $\mathrm{K}, \mathrm{Ti}$ and $\mathrm{Rb}$ show a very similar pattern throughout the past 1,100 years (Fig. 4). The first peaks of K, Ti and Rb are centred around AD 1350, followed by declines between ca. AD 1350 and ca. 1600. From ca. AD 1600, K, Ti and Rb increase gradually, followed by a more rapid increase in the 1850 s until reaching the highest values around AD 1900, followed by rapid reductions of $\mathrm{K}, \mathrm{Ti}$ and $\mathrm{Rb}$ until today. The values of $\mathrm{Zn}$

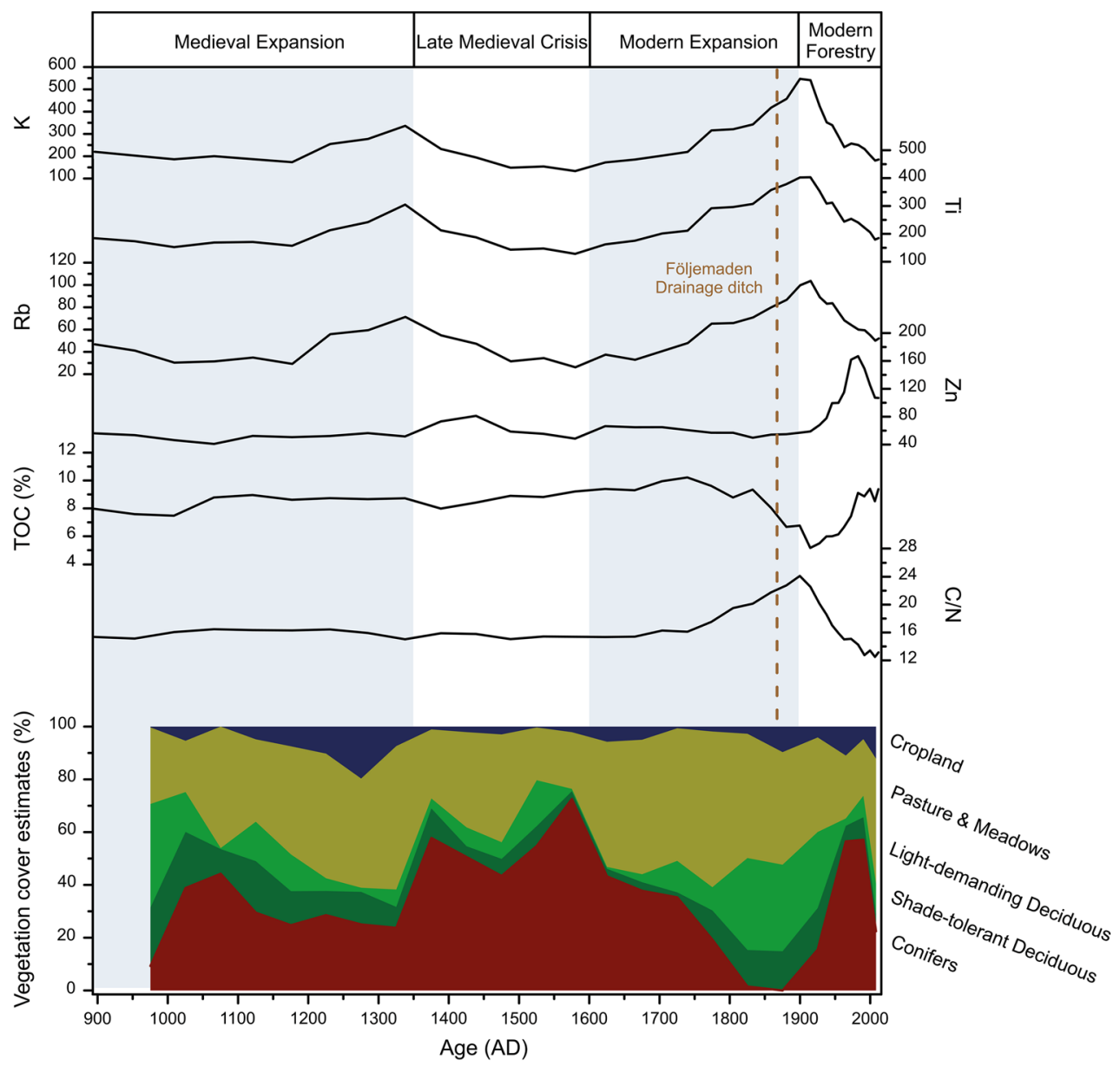

Fig. 4 X-ray fluorescence (XRF) data, total organic carbon (TOC) content, atomic $\mathrm{C} / \mathrm{N}$ ratio and LOVE-based estimates of local vegetation composition in percentage within the RSAP from Lake Skotte- nesjön. Relative concentration changes of $\mathrm{K}, \mathrm{Ti}, \mathrm{Rb}, \mathrm{Zn}$ are expressed as elemental intensity in counts per second (cps) 
stay rather low before ca. $\mathrm{AD} 1900$ and then increase rapidly, followed by a drop in the late 20th century.

\section{TOC content and $\mathrm{C} / \mathrm{N}$ ratio}

The records of sediment TOC content and $\mathrm{C} / \mathrm{N}$ ratio are shown in Fig. 4. TOC content has an average value of 8.2\% and ranges between 5.2 and $10.2 \%$. TOC values remain relatively constant before ca. AD 1350 and gently increase between ca. AD 1350 and ca. 1750. From ca. AD 1750, TOC values show a quite substantial decline until reaching a minimum value of $5.2 \%$ in the early $1900 \mathrm{~s}$. A rapid increase is recorded throughout most of the 20th century.

The $\mathrm{C} / \mathrm{N}$ ratio remains relatively low and nearly constant around 15.9 before ca. AD 1350 , followed by slightly lower values between ca. AD 1350 and ca. 1750, and then a substantial increase to a maximum of 24.1 around ca. AD 1900. After ca. AD 1900, the C/N ratio declines rapidly until the present.

\section{Discussion}

On the basis of combining the records of LOVE-derived vegetation cover estimates, TOC, $\mathrm{C} / \mathrm{N}$ and $\mathrm{XRF}$, the local land-use and associated soil erosion history for the catchment of Lake Skottenejön over the last 1,100 years can be divided into four phases: the Medieval expansion (ca. $A D$ 950-ca. 1350), the late Medieval crisis (ca. AD 1350-ca. 1600), the modern expansion (ca. AD 1600-ca. 1900) and the modern forestry (ca. AD 1900-present) (Fig. 4).

\section{Medieval expansion (ca. AD 950-ca. 1350)}

During this period, the local land-use was characterized by increased agricultural activities as indicated by the expansion of cropland (Fig. 4). This change is likely associated with the Medieval expansion as evidenced by other data from southern Sweden (Larsson 1975; Berglund 1991; Lindbladh and Bradshaw 1998; Lindbladh et al. 2000; Myrdal 2011; Lagerås 2013; Fredh et al. 2019). At the early stage of this period (ca. AD 950 to ca. 1150), the vegetation cover estimates show a decline in deciduous trees alongside an increase in Picea (Fig. 3). This was a result of a continuing expansion of Picea in this region, to which it had arrived just a few centuries earlier from the north (Björkman and Bradshaw 1996; Giesecke and Bennett 2004; Bradshaw and Lindbladh 2005). The increases in Cerealia-type and agricultural weeds, such as Rumex and Filipendula (Fig. 3), reflect the development of cultivation and forest grazing (Lagerås 1996; Lindbladh et al. 2000; Poska et al. 2004). The expansion of farming was possibly caused by an increase in population and settlement in this area during the High Middle Ages.
Strong population growth accompanied by agricultural expansion was seen throughout southern Sweden during this period (Larsson 1975; Berglund 1991; Lindbladh et al. 2000; Lagerås 2007, 2013; Myrdal 2011; Bragée et al. 2013).

A phase of elevated soil erosion is indicated by increases in $\mathrm{K}, \mathrm{Ti}$ and $\mathrm{Rb}$ between ca. AD 1200 and ca. 1350, which corresponds well with the expansion of cropland cover (Fig. 4). Previous studies have shown that erosion resulting from agricultural activities in a lake catchment commonly increases not only the amounts of minerogenic material, but also the input of terrestrial organic matter to the lake, which can be traced by increasing $\mathrm{C} / \mathrm{N}$ ratios and decrease in TOC content (Kaushal and Binford 1999; Meyers and Lallier-Vergés 1999; Routh et al. 2004; Das et al. 2009; Li et al. 2014). However, at Skottenesjön the constantly high values of TOC and low values of $\mathrm{C} / \mathrm{N}$ during the Medieval expansion (Fig. 4) suggest little change in terrestrial organic matter supply to sediment at this time. This is probably because of a relatively small-scale agrarian expansion during this period, not intensive enough in terms of forest disturbance to result in major erosion of organic-rich soils in the catchment. At this time, the ard was still the main soil treatment tool in this region of Sweden, where the plough only became widely used in the eighteenth century (Bringéus 2003). Thus, the soils were not deeply ploughed and disturbed, which could be another reason why increasing organic input is not observed.

\section{Late Medieval crisis (ca. AD 1350-ca. 1600)}

Between ca. AD 1350 and ca. 1600, the vegetation cover estimates indicate a decline in the pastures and meadows and especially in arable fields which in the late 1300s covered less than a quarter of the area they did a century earlier (Fig. 4). The abandonment of agricultural land was likely the consequence of population decline associated with the outbreaks of the plague at this time. The first plague epidemic (commonly known as "the black death") happened in most parts of Sweden in AD 1350 and was followed by several outbreaks in the second half of 14th century and at the beginning of the 15th century (Benedictow 2004; Myrdal 2012; Lagerås 2013). The population decline at Skogaryd, which is located in a marginal agricultural area, might not only indicate that the area was particularly badly struck by the plague, but could also reflect a migration to more central agricultural regions, such as the more fertile coastal plains, where abundant farmlands became available in the wake of plague outbreaks (Lagerås 2013; Fredh et al. 2019). The agricultural decline was at first followed by an increase in coniferous woodland cover dominated by Picea, which was still expanding in the region after its arrival (Fig. 3). A short period of decline in Picea cover is recorded in the vegetation cover estimates shortly after AD 1400 . This change 
was probably not caused by agricultural expansion since cropland cover remained at a low value at the same time (Fig. 3). This could imply that the Picea decline was instead the result of natural disturbances (e.g. fire, windfall or insect epidemics). A slight increase in Betula after the decrease of Picea is noted; Betula species are early-successional trees and can grow fast and be pioneers in disturbed forest areas when previously limited resources (light, moisture and nutrients) become available (Lagerås 1996; Sköld et al. 2010; Swanson et al. 2011). Later, at ca. AD 1550, Betula was again outcompeted by the late-successional Picea (Fig. 3).

A substantial decline in catchment erosion is seen at the onset of the Late Medieval crisis, indicated by much lower values of the lithogenic elements $(\mathrm{K}, \mathrm{Ti}, \mathrm{Rb})$ compared to the previous time period (Fig. 4). The slight decline in the $\mathrm{C} / \mathrm{N}$ ratio (Fig. 4) was likely caused by reduced terrestrial organic matter input (Meyers 1994), as a direct effect of increased forest cover on the catchment.

\section{Modern expansion (Ca. AD 1600-ca. 1900)}

The early stage of this period (ca. AD 1600-ca. 1700) is characterized by increasing cover of cropland, pasture and meadows and light-demanding trees at the expense of coniferous woodland (Fig. 4), which implies an expansion of animal grazing probably due to an increase in population in the study area (Lagerås et al. 1995; Lagerås 1996). The recovery of the population seems to have been rather slow, approximately half-a-century later compared to other areas in Sweden (Lagerås 2013), which is probably because the study site is located in a marginal area which was not the prime choice for settlement and farming. The short-lived expansion in agricultural and pastoral activity in the 1600s, recorded by elevated values of especially Cerealia-type, Rumex, Juniperus and Plantago (Fig. 3) may have been linked to the establishment of a manor house in the village Kyrkobyn (the church village) about $1.5 \mathrm{~km}$ from the western shore of Skottenesjön, which took place in the period AD 1669-77 (Hill 1999).

After the expansion, considerable abandonment of farmland in the catchment of Skottenesjön is indicated by the substantial decline in the cover of cropland from ca. AD 1700 to ca. AD 1850 (Fig. 4). Meanwhile, the historical records show an increase in the population of the Väne-Ryr Parish during this time period (Palm 2000). The surprising concurrence of population increase and decreased agriculture activity can probably be explained by a change in the settlement pattern within the parish recorded in the historical records. The manor house had been converted into an ordinary farm by $\mathrm{AD}$ 1700, and in 1730 the old church in Kyrkobyn was torn down and relocated to its current position in the village Väne-Ryr, in the catchment of lake Ryrsjön $2.5 \mathrm{~km}$ away (Fig. 1) (Hill 1999). This may have been accompanied by a shift in the main cultivation area of the parish resulting in less overlap with the relevant pollen source area of Skottenesjön, leading to a decrease in indicator pollen taxa of agricultural activity at this time, despite the increase in the human population at the parish scale.

Usually, an agricultural decline in Sweden is accompanied by the re-establishment of forest (Lagerås 2007; Fredh et al. 2012; Cui et al. 2014). However, the coniferous woodland dominated by Picea in the Lake Skottenesjön catchment continued to decrease throughout the 18th century and reached a minimum in the late 19th century (Fig. 3). The land-use in the study area during this period was different as compared to other areas in southern Sweden where agricultural development at the expense of woodland in modern time has been shown (e.g. Berglund et al. 2008; Hultberg et al. 2017). This difference can probably be explained by the special ownership and use of the forest which is today known as Skogaryd. In $\mathrm{AD} 1738$, the right to use timber from the forest was leased to the steel factory Kollerö Bruk, founded in the early 18th century (Hill 1999). The high demand for charcoal and wood fuel for the factory led to the gradual clearance of conifers (Fig. 3). The continued need of building material for the local farmers also contributed to the decline, although their extraction of timber from the forest was strictly regulated; a large number of court cases from the 18th and 19th century listed by Hill (1999) show that illegal tree felling in the forest was common. The need for labour both in the factory and in the forest for charcoal making (Hill 1999) may have contributed to the abandonment of farmland, and grazing in the forest also became regulated in an attempt to protect the valuable wood resources. The deforestation of conifers gave an opportunity for light-demanding tree species, particularly Betula, and shrubs like Juniperus to expand (Fig. 3).

The size of the local population reached a maximum in the late 19th century (Palm 2000) when the vegetation cover estimates also show a distinct increase in the cropland area, although pasture and meadow kept decreasing (Fig. 3). In order to deal with the demand for cropland, the wetland Följemaden in the Skogaryd forest was drained by ditching in the 1870s and used for cultivation, mainly for oats (Avena) (Hill 1999). Several small farmsteads were also established within the forest during the 19th century (Hill 1999), most of which are now either abandoned or used for occasional occupation, but not cultivation.

Significant elevations in the lithogenic elements $(\mathrm{K}, \mathrm{Ti}$, $\mathrm{Rb}$ ) were recorded in the sediment profile from ca. AD 1650 and they reached a maximum in ca. AD 1900 (Fig. 4). These changes reflect intensified catchment erosion associated with human activities including the clearance of coniferous woodland and the development of drainage systems during the modern expansion phase (Boyle 2001; Koinig et al. 2003; Kylander et al. 2011). Meanwhile, a distinct increase in $\mathrm{C} / \mathrm{N}$ ratio (from 16 to 24 ) (Fig. 4) was observed in response to 
elevated contribution of terrestrial organic matter to the sediments following the enhanced soil erosion (Meyers 1994). The input of terrestrial carbon started to accelerate from ca. AD 1750 when the coniferous area was deforested by about two thirds (Fig. 4). Simultaneously, the TOC content shows significantly decreasing values (Fig. 4), which was probably the result of the dilution of sediment organic matter by a massive the input of minerogenic matter to the sediments (Meyers and Lallier-Vergés 1999). Land-use during this period was much more intensive than during the Medieval expansion. The majority of the conifers were cut down for timber which led to a big change in forest structure (Fig. 3). The highly intensive use of forest contributed to elevated terrestrial organic matter delivery to the lake due to decreased soil stability. In addition, new technologies including ditching and more advanced ploughing techniques used for soil treatment were introduced to make farming more efficient (Magnusson 2000), which likely led to enhanced soil erosion. The elevated rates of both minerogenic and organic matter input are observed from the late 1800s (Fig. 4), which coincided with the establishment of the Följemaden drainage ditch close to the coring site in the 1870s, reflecting that the run-off through the ditching brought massive amounts of terrestrial detritus to the lake.

\section{Modern forestry (ca. AD 1900-present)}

The rapid increase in the conifers Pinus and Picea in the early 1900s at the expense of light-demanding trees, particularly Betula and Alnus (Fig. 3), suggests the establishment of coniferous plantations and the onset of modern forest management. The open land cover was reduced, but it was mainly pasture and meadows which declined, while there was an increase in cropland (Fig. 3). These changes are consistent with the general land-use changes in Sweden in the 20th century, where the traditional agricultural system with large areas for grazing and mowing was transformed into a landscape sharply divided into commercial forest and intensive crop cultivation (e.g. Björkman 2001; Åkesson et al. 2015; Mazier et al. 2015; Ning et al. 2018). A weak recovery of shade-tolerant deciduous species is observed (Fig. 3), which can be interpreted as the plantation of ornamental trees around farmlands and along roads (Gaillard et al. 1991; Rasmussen 2005). From the early 21 st century, the changes of vegetation cover estimates indicate a distinct increase in the openness in the study area (Fig. 3), which is likely attributed to clear-cutting of the managed forest.

The geochemical proxies indicate a drastic change in soil erosion to Lake Skottenesjön. The rapidly decreasing values of lithogenic elements $\mathrm{K}, \mathrm{Ti}$ and $\mathrm{Rb}$ reflect a large reduction in catchment erosion resulting from the reforestation (Fig. 4). The drop in $\mathrm{C} / \mathrm{N}$ ratios indicates that the contribution of land-derived organic matter substantially declined and that the contribution of aquatic organic matter dominated the lake sediments (Meyers and Teranes 2001). Sweden had started the transition from an agrarian country to an industrial country, and people moved to urban areas from the early 20th century (Bragée et al. 2013). The population in Väne-Ryr Parish began to decline from the 20th century, in response to the migration associated with the development of urban areas (Palm 2000). Haas et al. (2019) showed that recovery of the erosion regime after a population decline can take several centuries at some sites, whereas the situation at Skogaryd seems to be that the system responds much more rapidly, within a few decades. In the sediment profile, the influence of industrialization is represented by a peak in the heavy metal element Zn (Bragée et al. 2013), which declines again at the very top of the core, probably in response to modern control on industrial air pollution.

\section{Conclusions}

Human activities greatly affected the environmental changes in the Skogaryd area during the past 1,100 years. Variations in the TOC, TN and XRF data, as well as LRA estimated land-cover show that deforestation, agriculture, drainage and other human activities in the lake catchment modified the terrestrial organic and inorganic matter deposition in the lake. The results show that the Skogaryd area was very sensitive to variations in the extent and intensity of agricultural activities associated with societal changes. Between ca. AD 950 and ca. 1350, the local land use was characterized by small-scale agricultural activities associated with the Medieval expansion. Starting from ca. AD 1350, much of the farmland was abandoned and coniferous woodland cover expanded as a consequence of population decline due to plague outbreaks, and erosion in the catchment declined. In the 1600 s, agricultural land-use expanded again in response to the population increase, as seen in many other parts of Sweden. However, during the modern time, the land-use history of the study area, as reflected by both the LRA results and local historical records, differed from the general development of southern Sweden. From ca. AD 1700 to ca. 1850, abandonment of agriculture and deforestation of conifers are observed, which can be attributed to the high demand for fuel and labour for a local steel factory set up in the early 1700s and active until the late 1800s. The intensive use of the forest was accompanied by increased erosion. Artificial drainage was established to create more arable land to sustain the population in the late 19th century when the population in the area reached a maximum. This resulted in accelerated export of terrestrial organic matter from the catchment to the lake. From the 20th century, forestry management started with the plantations of Picea and Pinus, resulting in reduced input of both organic and minerogenic 
matter to the lake within a few decades. The findings of this study are helpful in completing the regional land-use history and for better understanding the impacts of land-use changes on elemental cycles in a long-term perspective, which are fundamental for the development of strategies for environmental management and ecosystem services.

Acknowledgements Open access funding provided by Lund University. This work was funded by the strategic research area BECC (Biodiversity and Ecosystem Services in a Changing Climate), The Royal Physiographic Society of Lund and China Scholarship Council (CSC). We thank Svante Björck for valuable comments, Leif Klemedtsson and David Allbrand for logistic support during the fieldwork, Tobias Rütting for the elemental analyses and Shinya Sugita for the REVEALS and LOVE programs.

Open Access This article is licensed under a Creative Commons Attribution 4.0 International License, which permits use, sharing, adaptation, distribution and reproduction in any medium or format, as long as you give appropriate credit to the original author(s) and the source, provide a link to the Creative Commons licence, and indicate if changes were made. The images or other third party material in this article are included in the article's Creative Commons licence, unless indicated otherwise in a credit line to the material. If material is not included in the article's Creative Commons licence and your intended use is not permitted by statutory regulation or exceeds the permitted use, you will need to obtain permission directly from the copyright holder. To view a copy of this licence, visit http://creativecommons.org/licenses/by/4.0/.

\section{References}

Abraham V, Kozáková R (2012) Relative pollen productivity estimates in the modern agricultural landscape of Central Bohemia (Czech Republic). Rev Palaeobot Palynol 179:1-12

Abraham V, Novák J, Houfková P, Petr L, Dudová L (2017) A landscape reconstruction algorithm and pedoanthracological data reveal Late Holocene woodland history in the lowlands of the NE Czech Republic. Rev Palaeobot Palynol 244:54-64

Åkesson C, Nielsen AB, Broström A, Persson T, Gaillard M-J, Berglund BE (2015) From landscape description to quantification: a new generation of reconstructions provides new perspectives on Holocene regional landscapes of SE Sweden. Holocene 25:178-193

Appleby PG (2001) Chronostratigraphic techniques in recent sediments. In: Last WM, Smol JP (eds) Tracking environmental change using lake sediments: basin analysis, coring, and chronological techniques. Springer, Dordrecht, pp 171-203. doi:https://doi.org/10.1007/0-306-47669-x_9

Aufgebauer A, Panagiotopoulos K, Wagner B et al (2012) Climate and environmental change in the Balkans over the last $17 \mathrm{ka}$ recorded in sediments from Lake Prespa (Albania/F.Y.R. of Macedonia/Greece). Quat Int 274:122-135

Balascio NL, Zhang Z, Bradley RS, Perren B, Dahl SO, Bakke J (2011) A multi-proxy approach to assessing isolation basin stratigraphy from the Lofoten Islands, Norway. Quat Res 75:288-300

Benedictow OJ (2004) The black death, 1346-1353: the complete history. Boydell Press, Woodbridge

Berglund BE (1991) The cultural landscape during 6000 years in southern Sweden- the Ystad Project. Ecological Bulletins 41. Munksgaard, Copenhagen
Berglund BE, Ralska-Jasiewiczowa M (1986) Pollen analysis and pollen diagrams. In: Berglund BE (ed) Handbook of holocene palaeoecology and palaeohydrology. Wiley, Chichester, pp 455-484

Berglund BE, Gaillard M-J, Björkman L, Persson T (2008) Long-term changes in floristic diversity in southern Sweden: palynological richness, vegetation dynamics and land-use. Veget Hist Archaeobot 17:573-583

Björck S, Digerfeldt G (1991) Allerød-Younger Dryas sea level changes in southwestern Sweden and their relation to the Baltic Ice Lake development. Boreas 20:115-133

Björkman L (2001) The role of human disturbance in Late Holocene vegetation changes on Kullaberg, southern Sweden. Veget Hist Archaeobot 10:201-210

Björkman L, Bradshaw R (1996) The immigration of Fagus sylvatica L. and Picea abies (L.) Karst. into a natural forest stand in southern Sweden during the last 2000 years. J Biogeogr 23:235-244

Blaauw M (2010) Methods and code for 'classical' age-modelling of radiocarbon sequences. Quat Geochronol 5:512-518

Boyle JF (2001) Inorganic geochemical methods in palaeolimnology. In: Last WM, Smol JP (eds) Tracking environmental change using lake sediments: physical and geochemical methods. Springer, Dordrecht, pp 83-141. https://doi.org/10.1007/0-30647670-3 5

Bradshaw RHW, Lindbladh M (2005) Regional spread and stand-scale establishment of Fagus sylvatica and Picea abies in Scandinavia. Ecology 86:1,679-1,686.

Bragée P, Choudhary P, Routh J, Boyle JF, Hammarlund D (2013) Lake ecosystem responses to catchment disturbance and airborne pollution: an 800-year perspective in southern Sweden. J Paleolimnol 50:545-560

Bringéus N-A (2003) Arbete och redskap: materiell folkkultur på svensk landsbygd före industrialismen, 5th edn. Carlsson, Stockholm

Broström A, Sugita S, Gaillard MJ (2004) Pollen productivity estimates for the reconstruction of past vegetation cover in the cultural landscape of southern Sweden. Holocene 14:368-381

Campeau A, Bishop K, Nilsson MB et al (2018) Stable carbon isotopes reveal soil-stream DIC linkages in contrasting headwater catchments. J Geophys Res Biogeosci 123:149-167

Chmiel HE, Kokic J, Denfeld BA et al. (2016) The role of sediments in the carbon budget of a small boreal lake. Limnol Oceanogr $61: 1,814-1,825$.

Croudace I, Rindby A, Rothwell RG (2006) ITRAX: Description and evaluation of a new multi-function X-ray Core Scanner. In: Rothwell RG (ed) New techniques in sediment core analysis. Geological Society Special Publications 267. The Geological Society of London, London, pp 51-63. https://doi.org/10.1144/ GSL.SP.2006.267.01.04

Cui Q-Y, Gaillard M-J, Lemdahl G, Sugita S, Greisman A, Jacobson GL, Olsson F (2013) The role of tree composition in Holocene fire history of the hemiboreal and southern boreal zones of southern Sweden, as revealed by the application of the landscape reconstruction algorithm: implications for biodiversity and climate-change issues. Holocene 23:1747-1763

Cui Q-Y, Gaillard M-J, Lemdahl G, Stenberg L, Sugita S, Zernova G (2014) Historical land-use and landscape change in southern Sweden and implications for present and future biodiversity. Ecol Evol 4:3555-3570

Das BK, Haake B-G (2003) Geochemistry of Rewalsar Lake sediment, Lesser Himalaya, India: implications for source-area weathering, provenance and tectonic setting. Geosci J 7:299-312

Das B, Narwani A, Matthews B, Nordin R, Mazumder A (2009) Anthropogenic disturbance history influences the temporal coherence of paleoproductivity in two lakes. J Paleolimnol $42: 167-181$ 
Davies SJ, Lamb HF, Roberts SJ (2015) Micro-XRF core scanning in palaeolimnology: recent developments. In: Croudace IW, Rothwell RG (eds) Micro-XRF studies of sediment cores: applications of a non-destructive tool for the environmental sciences. Springer, Dordrecht, pp 189-226. https://doi. org/10.1007/978-94-017-9849-5_7

Duarte CM, Conley DJ, Carstensen J, Sánchez-Camacho M (2009) Return to neverland: shifting baselines affect eutrophication restoration targets. Estuaries Coasts 32:29-36

Eisenhut G (1961) Untersuchungen über die Morphologie und Ökologie der Pollenkörner heimischer und fremdländischer Waldbäume. Paul Parley, Hamburg und Berlin

Espi E, Boutron CF, Hong S, Pourchet M, Ferrari C, Shotyk W, Charlet $\mathrm{L}$ (1997) Changing concentrations of $\mathrm{Cu}, \mathrm{Zn}, \mathrm{Cd}$ and $\mathrm{Pb}$ in a high altitude peat bog from Bolivia during the past three centuries. Water Air Soil Pollut 100:289-296

Fredh D, Broström A, Zillén L, Mazier F, Rundgren M, Lagerås P (2012) Floristic diversity in the transition from traditional to modern land-use in southern Sweden A.D. 1800-2008. Veget Hist Archaeobot 21:439-452

Fredh D, Mazier F, Bragée P, Lagerås P, Rundgren M, Hammarlund D, Broström A (2017) The effect of local land-use changes on floristic diversity during the past 1000 years in southern Sweden. Holocene 27:694-711

Fredh ED, Lagerås P, Mazier F, Björkman L, Lindbladh M, Broström A (2019) Farm establishment, abandonment and agricultural practices during the last 1,300 years: a case study from southern Sweden based on pollen records and the LOVE model. Veget Hist Archaeobot 28:529-544

Fries M (1951) Pollenanalytiska vittnesbörd om senkvartär vegetationsutveckling, särskilt skogshistoria, i nordvästra Götaland. Acta phytogeographica Suecics 29. Svenska Växtgeografiska Sällskapet, Uppsala

Gaillard M-J, Dearing JA, El-Daoushy F, Enell M, Håkansson H (1991) A late Holocene record of land-use history, soil erosion, lake trophy and lake-level fluctuations at Bjäresjösjön (south Sweden). J Paleolimnol 6:51-81

Giesecke T, Bennett KD (2004) The Holocene spread of Picea abies (L.) Karst. in Fennoscandia and adjacent areas. J Biogeogr $31: 1,523-1,548$

Gregory PH (1973) The microbiology of the atmosphere. Leonard Hill, Aylesbury

Guilizzoni P, Marchetto A, Lami A et al (1996) The environmental history of a mountain lake (Lago Paione Superiore, Central Alps, Italy) for the last c. 100 years: a multidisciplinary, paleolimnological study. J Paleolimnol 15:245-264

Haas M, Baumann F, Castella D et al (2019) Roman-driven cultural eutrophication of Lake Murten, Switzerland. Earth Planet Sci Lett 505:110-117

Hill Ö (1999) Skogaryd: en skogshistoria. Dahlins, Borås

Hjelle KL (1998) Herb pollen representation in surface moss samples from mown meadows and pastures in western Norway. Veget Hist Archaeobot 7:79-96

Hjelle KL, Lødøen TK (2017) Dating of rock art and the effect of human activity on vegetation: The complementary use of archaeological and scientific methods. Quat Sci Rev 168:194-207

Hultberg T, Gaillard M-J, Grundmann B, Lindbladh M (2015) Reconstruction of past landscape openness using the Landscape Reconstruction Algorithm (LRA) applied on three local pollen sites in a southern Swedish biodiversity hotspot. Veget Hist Archaeobot 24:253-266

Hultberg T, Lagerås P, Björkman L, Sköld E, Jacobson GL, Hedwall P-O, Lindbladh M (2017) The late-Holocene decline of Tilia in relation to climate and human activities - pollen evidence from 42 sites in southern Sweden. J Biogeogr 44:2,398-2,409
Kaushal S, Binford MW (1999) Relationship between C: N ratios of lake sediments, organic matter sources, and historical deforestation in Lake Pleasant, Massachusetts, USA. J Paleolimnol 22:439-442

Klamt A-M, Jensen HS, Mortensen MF, Schreiber N, Reitzel K (2017) The importance of catchment vegetation for alkalinity, phosphorus burial and macrophytes as revealed by a recent paleolimnological study in a soft water lake. Sci Total Environ 580:1,097-1,107

Klemedtsson L, Ernfors M, Björk RG, Weslien P, Rütting T, Crill P, Sikström U (2010) Reduction of greenhouse gas emissions by wood ash application to a Picea abies (L.) Karst. forest on a drained organic soil. Eur J Soil Sci 61:734-744

Koinig KA, Shotyk W, Lotter AF, Ohlendorf C, Sturm M (2003) 9000 years of geochemical evolution of lithogenic major and trace elements in the sediment of an alpine lake -the role of climate, vegetation, and land-use history. J Paleolimnol 30:307-320

Kokic J, Sahlée E, Brand A, Sobek S (2016) Low sediment-water gas exchange in a small boreal lake. J Geophys Res Biogeosci $121: 2,493-2,505$

Köster D, Pienitz R, Wolfe BB, Barry S, Foster DR, Dixit SS (2005) Paleolimnological assessment of human-induced impacts on Walden Pond (Massachusetts, USA) using diatoms and stable isotopes. Aquat Ecosyst Health Manage 8:117-131

Kylander ME, Ampel L, Wohlfarth B, Veres D (2011) High-resolution $\mathrm{X}$-ray fluorescence core scanning analysis of Les Echets (France) sedimentary sequence: new insights from chemical proxies. J Quat Sci 26:109-117

Lagerås P (1996) Farming and forest dynamics in an agriculturally marginal area of southern Sweden, 5000 BC to present: a palynological study of Lake Avegöl in the Småland Uplands. Holocene 6:301-314

Lagerås P (2007) The ecolocy of expansion and abandonment: medieval and post-medieval agriculture and settlement in a landscape perspective. Riksantikvarieämbetet, Stockholm

Lagerås P (2013) Medieval colonisation and abandonment in the south Swedish uplands: a review of settlement and land use dynamics inferred from the pollen record. Archaeol Baltica 20:77-90

Lagerås P, Jansson K, Vestbö A (1995) Land-use history of the Axlarp area in the Småland uplands, southern Sweden: palaeoecological and archaeological investigations. Veget Hist Archaeobot $4: 223-234$

Larsson L-O (1975) Det Medeltida Värend. Kronobergsboken 197475. Kronobergs Läns hembygdsförbund, Växjö, Sweden

Li L, Yu Z, Moeller RE, Bebout GE (2008) Complex trajectories of aquatic and terrestrial ecosystem shifts caused by multiple human-induced environmental stresses. Geochim Cosmochim Acta $72: 4,338-4,351$

Li S, Hu X, Tang Y, Huang C, Xiao W (2014) Changes in lacustrine environment due to anthropogenic activities over 240 years in Jiuzhaigou National Nature Reserve, southwest China. Quat Int 349:367-375

Lindbladh M, Bradshaw R (1998) The origin of present forest composition and pattern in southern Sweden. J Biogeogr 25:463-477

Lindbladh M, Bradshaw R, Holmqvist BH (2000) Pattern and process in south Swedish forests during the last 3000 years, sensed at stand and regional scales. J Ecol 88:113-128

Lu Y, Fritz SC, Stone JR, Krause TR, Whitlock C, Brown ET, Benes JV (2017) Trends in catchment processes and lake evolution during the late-glacial and early- to mid-Holocene inferred from highresolution XRF data in the Yellowstone region. J Paleolimnol 58:551-569

Magnusson L (2000) An economic history of Sweden. Routledge, London

Mazier F, Broström A, Gaillard M-J, Sugita S, Vittoz P, Buttler A (2008) Pollen productivity estimates and relevant source area of 
pollen for selected plant taxa in a pasture woodland landscape of the Jura Mountains (Switzerland). Veget Hist Archaeobot 17:479-495

Mazier F, Gaillard M-J, Kuneš P, Sugita S, Trondman A-K, Broström A (2012) Testing the effect of site selection and parameter setting on REVEALS-model estimates of plant abundance using the Czech quaternary palynological database. Rev Palaeobot Palynol 187:38-49

Mazier F, Broström A, Bragée P et al (2015) Two hundred years of land-use change in the South Swedish Uplands: comparison of historical map-based estimates with a pollen-based reconstruction using the landscape reconstruction algorithm. Veget Hist Archaeobot 24:555-570

Mehl IK, Overland A, Berge J, Hjelle KL (2015) Cultural landscape development on a west-east gradient in western Norwaypotential of the Landscape Reconstruction Algorithm (LRA). J Archaeol Sci 61:1-16

Meyers PA (1994) Preservation of elemental and isotopic source identification of sedimentary organic matter. Chem Geol 114:289-302

Meyers PA (2003) Applications of organic geochemistry to paleolimnological reconstructions: a summary of examples from the Laurentian Great Lakes. Org Geochem 34:261-289

Meyers PA, Lallier-Vergés E (1999) Lacustrine sedimentary organic matter records of late quaternary Paleoclimates. J Paleolimnol 21:345-372

Meyers PA, Teranes JL (2001) Sediment organic matter. In: Last WM, Smol JP (eds) Tracking environmental change using lake sediments: physical and geochemical methods. Springer, Dordrecht, pp 239-269. https://doi.org/10.1007/0-306-47670-3_9

Myrdal J (2011) Farming and feudalism: 1000-1700. In: Myrdal J, Morell M (eds) The agrarian history of Sweden: from 4000 BC to AD 2000. Nordic Academic Press, Lund, pp 72-117

Myrdal J (2012) Agrarian change and crisis in Europe, 1200-1500. Routledge, New York

Natchimuthu S, Sundgren I, Gålfalk M, Klemedtsson L, Crill P, Danielsson $\AA$, Bastviken D (2016) Spatio-temporal variability of lake $\mathrm{CH}_{4}$ fluxes and its influence on annual whole lake emission estimates. Limnol Oceanogr 61(Suppl 1):S13-S26

Neumann T, Stögbauer A, Walpersdorf E, Stüben D, Kunzendorf H (2002) Stable isotopes in recent sediments of Lake Arendsee, NE Germany: response to eutrophication and remediation measures. Palaeogeogr Palaeoclimatol Palaeoecol 178:75-90

Nielsen AB (2004) Modelling pollen sedimentation in Danish lakes at c. AD 1800: an attempt to validate the POLLSCAPE model. J Biogeogr 31:1,693-1,709

Nielsen AB, Odgaard BV (2010) Quantitative landscape dynamics in Denmark through the last three millennia based on the landscape reconstruction algorithm approach. Veget Hist Archaeobot 19:375-387

Ning W, Nielsen AB, Norbäck Ivarsson L et al (2018) Anthropogenic and climatic impacts on a coastal environment in the Baltic Sea over the last 1000 years. Anthropocene 21:66-79

Olid C, Garcia-Orellana J, Martínez-Cortizas A, Masqué P, PeiteadoVarela E, Sanchez-Cabeza J-A (2010) Multiple site study of recent atmospheric metal $(\mathrm{Pb}, \mathrm{Zn}$ and $\mathrm{Cu})$ deposition in the NW Iberian Peninsula using peat cores. Sci Total Environ 408:5,540-5,549

Overballe-Petersen MV, Nielsen AB, Bradshaw RHW (2013) Quantitative vegetation reconstruction from pollen analysis and historical inventory data around a Danish small forest hollow. J Veget Sci 24:755-771

Palm LA (2000) Folkmängden i Sveriges socknar och kommuner 15711997: med särskild hänsyn till perioden 1571-1751. Palm, Visby

Poska A, Saarse L, Veski S (2004) Reflections of pre- and early-agrarian human impact in the pollen diagrams of Estonia. Palaeogeogr Palaeoclimatol Palaeoecol 209:37-50
Randsalu-Wendrup L, Conley DJ, Carstensen J, Fritz SC (2016) Paleolimnological records of regime shifts in lakes in response to climate change and anthropogenic activities. J Paleolimnol 56:1-14

Rasmussen P (2005) Mid-to late-Holocene land-use change and lake development at Dallund S $\varnothing$, Denmark: vegetation and land-use history inferred from pollen data. Holocene 15:1,116-1,129

Reimer PJ, Bard E, Bayliss A et al (2013) IntCal13 and Marine13 radiocarbon age calibration curves $0-50,000$ Years cal BP. Radiocarbon 55:1,869-1,887

Renberg I, Hansson H (2008) The HTH sediment corer. J Paleolimnol 40:655-659

Routh J, Meyers PA, Gustafsson Ö, Baskaran M, Hallberg R, Schöldström A (2004) Sedimentary geochemical record of humaninduced environmental changes in the Lake Brunnsviken watershed, Sweden. Limnol Oceanogr 49:1,560-1,569

Rütting T, Björk RG, Meyer A, Klemedtsson L, Sikström U (2014) Reduced global warming potential after wood ash application in drained Northern peatland forests. For Ecol Manage 328:159-166

SGU (2016) Map generator, Shore-level. https://apps.sgu.se/kartgenera tor/maporder_en.html. Accessed 15 Feb 2019

Shotyk W (1996) Natural and anthropogenic enrichments of $\mathrm{As}, \mathrm{Cu}, \mathrm{Pb}$, $\mathrm{Sb}$, and $\mathrm{Zn}$ in ombrotrophic versus minerotrophic peat bog profiles, Jura Mountains, Switzerland. Water Air Soil Pollut 90:375-405

SITES (2015) Skogaryd Research Station. https://www.fieldsites.se/ en-GB/about-sites/field-research-stations/skogaryd-32652394. Accessed 15 Feb 2019

Sköld E, Lagerås P, Berglund BE (2010) Temporal cultural landscape dynamics in a marginal upland area: agricultural expansions and contractions inferred from palynological evidence at Yttra Berg, southern Sweden. Veget Hist Archaeobot 19:121-136

Sugita S (2007a) Theory of quantitative reconstruction of vegetation I: pollen from large sites REVEALS regional vegetation composition. Holocene 17:229-241

Sugita S (2007b) Theory of quantitative reconstruction of vegetation II: all you need is LOVE. Holocene 17:243-257

Sugita S, Gaillard M-J, Broström A (1999) Landscape openness and pollen records: a simulation approach. Holocene 9:409-421

Swanson ME, Franklin JF, Beschta RL et al (2011) The forgotten stage of forest succession: early-successional ecosystems on forest sites. Front Ecol Environ 9:117-125

Talbot MR (2001) Nitrogen isotopes in palaeolimnology. In: Last WM, Smol JP (eds) Tracking environmental change using lake sediments: physical and geochemical methods. Springer, Dordrecht, pp 401-439. https://doi.org/10.1007/0-306-47670-3_15.

Tarvainen L, Räntfors M, Wallin G (2014) Vertical gradients and seasonal variation in stem $\mathrm{CO}_{2}$ efflux within a Norway spruce stand. Tree Physiol 34:488-502

Tauber H (1977) Investigations of aerial pollen transport in a forested area. Dansk Botanisk Aarkiv 32:5-84

Thompson R, Stober JC, Turner GM, Oldfield F, Bloemendal J, Dearing JA, Rummery TA (1980) Environmental applications of magnetic measurements. Science 207:481-486

Wallin MB, Campeau A, Audet J et al (2018) Carbon dioxide and methane emissions of Swedish low-order streams-a national estimate and lessons learnt from more than a decade of observations. Limnol Oceanogr Lett 3:156-167

Williams M (2000) Dark ages and dark areas: global deforestation in the deep past. J Hist Geogr 26:28-46

Willis KJ, Birks HJB (2006) What is natural? the need for a longterm perspective in biodiversity conservation. Science $314: 1,261-1,265$

Publisher's Note Springer Nature remains neutral with regard to jurisdictional claims in published maps and institutional affiliations. 